Jurnal Ners Volume 4 Nomor 1 Tahun 2020 Halaman 29 - 34

JURNAL NERS

Research \& Learning in Nursing Science

http://journal.universitaspahlawan.ac.id/index.php/ners

\title{
EFEKTIFITAS KOMPRES SEREI HANGAT TERHADAP PENURUNAN SKALA NYERI ARTHRITIS RHEUMATOID PADA LANSIA DI DESA NAUMBAI WILAYAH KERJA PUSKESMAS KAMPAR
}

\author{
Ridha Hidayat \\ Program Studi Sarjana Keperawatan \\ Universitas Pahlawan Tuanku Tambusai \\ hidayat22131120@gmail.com
}

\begin{abstract}
Abstrak
Arthritis rematoid seringkali melibatkan organ tubuh lainnya yang disertai nyeri dan kaku pada system otot dan jaringan ikat.Penelitian ini bertujuan untuk mengetahui efektifitas kompres serai hangat terhadap skala nyeri arthritis rematoid pada lansia di Desa Naumbai Wilayah Kerja Puskesmas Kampar.Metode penelitian ini adalah Quasi Eksperimen dalam satu kelompok (one group pre test-pos test design). Populasi adalah seluruh pasien arthritis rheumatoid di Desa Naumbai dengan jumlah 127 orang. Adapun penentuan sampel menggunakan purposive sampling, jumlah sampel pada penelitian ini sebanyak 33 orang. Instrumen yang digunakan adalah lembar observasi dan Numerical Rating Scale dan Skala nyeri wajah. Analisa yang digunakan adalah analisa univariat dan bivariate dengan menggunakan uji T-Dependent. Hasil penelitian menunjukkan adanya perbedaan secara bermakna antara skala nyeri responden setelah diberikan kompres serai hangat dengan nilai $p$-value $(0,000)<\alpha(0,05)$. Diharapkan penderita arthritis rheumatoid dengan nyeri dapat mengaplikasikan kompres serai hangat untuk penurunan skala nyeri.
\end{abstract}

\section{Kata Kunci : Skala nyeri, kompres serai hangat}

Corresponding author :

Address : Jl. Tuanku Tambusai No. 23 Bangkinang

Email : hidayat22131120@gmail.com

Phone : 081365317266 


\section{PENDAHULUAN}

Perubahan - perubahan akan terjadi pada tubuh sejalan dengan makin meningkatnya usia. Perubahan tubuh terjadi sejak awal kehidupan hingga usia lanjut pada semua organ dan jaringan tubuh. Keadaan demikian itu tampak pula pada semua sistem muskuloskeletal dan jaringan lain yang ada kaitannya dengan kemungkinan timbulnya beberapa golongan Rheumatoid (Idris, 2010). Athritis Rheumatoid (RA) adalah kelainan inflamasi yang terutama mengenai membran sinovial dari persendian dan umumnya ditandai dengan nyeri persendian, kaku sendi, penurunan mobilitas dan keletihan. (Baughman 2000).

Rheumatoid bukan merupakan suatu penyakit, tapi merupakan suatu sindrom dan golongan penyakit yang menampilkan perwujudan sindroma Rheumatoid cukup banyak, namun semuanya mewujudkan adanya persamaan ciri maupun di negara yang sedang berkembang (Mansjoer Arif, 2001).

Penyakit ini merupakan suatu penyakit autoimun yang ditandai dengan terdapatnya sinovitis erosive simetrik yang walaupun terutama mengenai jaringan persendian, seringkali juga melibatkan organ tubuh lainya yang disertai nyeri dan kaku pada sistem otot (musculoskeletal) dan jaringan ikat/ connective tissue (Sudoyo, 2007). Lebih mudahnya Arthritis Rheumatoid diartikan sebagai penyakit yang menyerang sendi, otot, dan jaringan tubuh (Utami, 2005).

Namun begitu banyak aktivitas keperawatan nonfarmakologi yang dapat digunakan untuk menghilangkan nyeri. Metode penghilang nyeri nonfarmakologi biasanya mempunyai resiko lebih rendah. Meskipun tindakan tersebut bukan merupakan pengganti untuk obat-obatan, tindakan tersebut mungkin dapat mempersingkat episode nyeri (Smeltzer, 2001).

Salah satu tindakan untuk menghilangkan nyeri secara nonfarmakologi yaitu dengan menghangatkan persendian yang sakit. Mekanisme metode ini sama dengan metode terapi pijat yang menggunakan terapi gate kontrol. Ada bermacam-macam cara pemanasan yaitu kompres hangat dengan handuk, dengan mendekatkan botol ke kedua sendi yang sakit dan bisa juga dengan berjemur di bawah sinar matahari. Penggunaan panas mempunyai keuntungan meningkatkan aliran darah ke suatu area dan kemungkinan dapat turut menurunkan nyeri, panas yang lembab dapat menghilangkan kekakuan pada pagi hari akibat Arthritis (Ceccio, 1990 dalam Potter,Perry, 2001).

Organisasi kesehatan dunia (WHO) melaporkan bahwa 20\%, penduduk dunia terserang penyakit Arthritis Rheumatoid . Dimana $5-10 \%$ adalah mereka yang berusia

5-20 tahun dan 20\% mereka yang berusia 55 tahun (Wiyono, 2010). Lebih dari 355 juta orang di dunia ternyata menderita penyakit rematik. Itu berarti, setiap enam orang di dunia ini satu di antaranya adalah penyandang Rheumatoid yang mana jumlah penduduk dunia tahun 2012 sebanyak kurang lebih 7 miliar jiwa. Diperkirakan angka ini terus meningkat hingga tahun 2025 dengan indikasi lebih dari $25 \%$ akan mengalami kelumpuhan.

Pada survey pendahuluan yang dilakukan peneliti Tanggal 10 maret 2019 pada 10 orang masyarakat yang menderita Arthritis Rheumatoid Di Desa Naumbai Wilayah Kerja Puskesmas Kampar, didapatkan 6 dari 10 orang penderita Arthritis Rheumatoid mengatakan keluhan utama yang dirasakan adalah nyeri pada persendian, 5 dari 10 mengatakan bahwa aktivitasnya sangat terganggu karena adanya nyeri. Berdasarkan latar belakang yang telah diuraikan diatas maka peneliti tertarik untuk melakukan penelitian dengan judul "Efektifitas Kompres Serai Hangat Terhadap Penurunan Skala Nyeri Arthritis Rheumatoid pada Lansia di Desa Naumbai Wilayah Kerja Puskesmas Kampar tahun 2019

\section{METODOLOGI PENELITIAN}

Penelitian ini menggunakan Quasi Eksperimen dalam satu kelompok (one group pre test - post test design). Rancangan ini merupakan bentuk desain eksperimen yang lebih baik validitas internalnya dari pada rancangan pre-eksperimental dan lebih lemah dari true eksperimental. Desain 
ini terdiri atas time series, nonequivalent control group design, equevalen time sample design yang dalam rancangan ini, pada sampel penelitian, sebelum dilaksanakannya perlakuan dilakukan observasi beberapa kali dan sesudah perlakuan juga dilakukan beberapa kali observasi (Hidayat A A, 2009).

Penelitian ini dilakukan pada lansia penderita Arthritis Reumatoiddi Desa Naumbai Wilayah Kerja Puskesmas Kampar. Penelitian ini dilaksanakan pada Tanggal 13-17 Agustus 2019.

Populasi dalam penelitian ini adalah seluruh Lansia penderita Arthritis Rheumathoid di Desa Naumbai yang berjumlah sebanyak 127 kasus. Alat pengumpulan data yang digunakan pada penelitian ini yaitu berupa pemeriksaan skala nyeri dan lembar observasi. Analisa data yang digunakan dalam penelitian ini adalah analisa univariat dan bivariat

\section{HASIL PENELITIAN}

Penelitian ini bertujuan untuk menganalisis Efektifitas kompres serai hangat terhadap penurunan skala nyeri arthritis rematoid pada lansia di Desa Naumbai Wilayah Kerja Puskesmas Kampar. Penelitian ini dilakukan pada tanggal 13 Agustus sampai 17 Agustus 2019. Analisa data yang dilakukan dalam penelitian ini berupa analisa Univariat dan Bivariat.
A. Karakteristik Responden
1. Umur

Tabel 4.1 : Distribusi frekuensi umur responden $(n=33)$

\begin{tabular}{l|l|l}
\hline Variabel & & $\%$ \\
\hline Umur & & \\
\hline a.45-59 tahun & 8 & $24,2 \%$ \\
\hline b.60-74 tahun & 22 & $66,7 \%$ \\
\hline c. 75-90 tahun & 3 & $9,1 \%$ \\
\cline { 1 - 2 } Total & 33 & $100 \%$ \\
\cline { 1 - 2 }
\end{tabular}

Berdasarkan tabel 4.1 diketahui bahwa umur responden sebagian besar berada dalam kelompok usia lanjut "elderly" ( 60-74 tahun) yaitu sebanyak 22 orang $(66,7 \%)$.
2. Jenis kelamin

\section{2 : Distribusi Frekuensi Jenis Kelamin} Responden

\begin{tabular}{l|l|l}
\hline Variabel & F & $\%$ \\
\hline Jenis Kelmain & & \\
\hline a.Perempuan & 20 & $60,6 \%$ \\
\hline b.Laki - laki & 13 & 39,4 \\
\hline \multicolumn{1}{c}{ Total } & 33 & $100 \%$ \\
\hline
\end{tabular}

\section{B. Analisa Univariat}

Analisa univariat dilakukan untuk melihat distribusi karakteristik responden, skala nyeri sebelum dan sesudah pemberian kompres serai hangat

Tabel 4.3 : Distribusi frekuensi skala nyeri responden sebelum pemberian kompres hangat

\begin{tabular}{l|l|l|l}
\hline Variabel & Mean & $\begin{array}{l}\text { Std. } \\
\text { Deviasi }\end{array}$ & $\begin{array}{l}\text { Min } \\
\text { Max }\end{array}$ \\
\hline $\begin{array}{l}\text { Skala nyeri sebelum } \\
\text { kompres serai hangat }\end{array}$ & 4,94 & 0,864 & $3-6$ \\
\hline $\begin{array}{l}\text { Berdasarkan tabel 4.3 dapat dilihat bahwa } \\
\text { rata-rata skala nyeri sebelum pemberian }\end{array}$
\end{tabular}
kompres serai hangat adalah 4,94 dengan standar deviasi 0,864

Tabel 4.4 : Distribusi frekuensi skala nyeri responden sesudah pemberian kompres serai hangat

\begin{tabular}{l|l|l|l}
\hline Variabel & Mean & $\begin{array}{l}\text { Std. } \\
\text { Deviasi }\end{array}$ & $\begin{array}{l}\text { Min } \\
\text { Max }\end{array}$ \\
\hline $\begin{array}{l}\text { Skala nyeri } \\
\text { sebelum kompres } \\
\text { serai hangat }\end{array}$ & 2,97 & 0,68 & $2-4$ \\
\hline \multicolumn{2}{l|l}{. } & & \\
\hline
\end{tabular}
rata-rata skala nyeri sesudah diberikan kompres serai hangat adalah 2,97 dengan standar deviasi 0,684 .

Tabel 4.5 : Distribusi frekuensi skala nyeri responden sebelum kompres serai hangat

\begin{tabular}{c|l|l}
\hline Skala nyeri & $\mathbf{F}$ & $\mathbf{\%}$ \\
\hline 1. Nyeri Ringan & 1 & $3,0 \%$ \\
\hline 2. Nyeri sedang & 32 & $97,0 \%$ \\
\hline Total & 33 & $100 \%$ \\
\hline
\end{tabular}


Berdasarkan tabel 4.5 dapat dilihat bahwa rata-rata skala nyeri responden sebelum diberikan serai hangat ialah berada pada tingkat nyeri sedang yaitu sebanyak 32 orang $(97,0 \%)$.

Tabel 4.6 : Distribusi frekuensi skala nyeri responden sesudah kompres serai hangat

\begin{tabular}{l|l|l}
\hline Skala nyeri & $\mathrm{F}$ & $\%$ \\
\hline 1. Nyeri Ringan & 26 & $78,8 \%$ \\
\hline 2. Nyeri sedang & 7 & $21,2 \%$ \\
\hline Total & 33 & $100 \%$ \\
\hline
\end{tabular}

Berdasarkan tabel 4.6 dapat dilihat bahwa rata-rata skala nyeri responden setelah kompres serai hangat ialah berada pada tingkat skala nyeri ringan yaitu sebanyak 26 orang $(78,8$ $\%)$.

\section{Analisa Bivariat}

Analisa bivariate dilakukan untuk melihat perbandingan penurunan skala nyeri sebelum dan sesudah diberikan kompres serai hangat.

Tabel 4.7 : Efektifitas kompres serai hangat terhadap penurunan skala nyeri Arthritis rheumatoid pada lansia di Desa Naumbai
Wilayah puskesmas kampar

\begin{tabular}{|c|c|c|c|}
\hline VARIABEL & MEAN & $\begin{array}{l}\text { STD } \\
\text { DEVIASI }\end{array}$ & $\begin{array}{l}\text { P } \\
\text { VALUE }\end{array}$ \\
\hline $\begin{array}{l}\text { Skala nyeri } \\
\text { sebelum kompres } \\
\text { serai hangat }\end{array}$ & 4,94 & 0,864 & 0,000 \\
\hline $\begin{array}{l}\text { Skala nyeri } \\
\text { sesudah kompres } \\
\text { serai hangat }\end{array}$ & 2,97 & 0,684 & \\
\hline
\end{tabular}

Berdasrkan tabel 4.7 dapat dilihat bahwa terdapat perbedaan rata-rata nilai mean sebelum kompres serai hangat (pretest) sebesar 4,94 dan sesudah kompres serai hangat (postest) sebesar 2,97 dan nilai P- value sebesar 0,000 $(\mathrm{p}<0,05)$, artinya ada perbedaan skala nyeri responden sebelum dan sesudah kompres serai hangat

\section{PEMBAHASAN}

Berdasarkan penelitian dengan judul “ Efektifitas Kompres Serei Hangat Terhadap Penurunan Skala Nyeri Arthritis Rheumatoid pada Lansia di Desa Naumbai Wilayah Kerja Puskesmas Kampar 2019, hasil penelitian yang dilakukan terhadap 33 responden diperoleh sebagian besar responden berada dalam kelompok usia lanjut "elderly" (60-74 tahun) sebanyak 22 orang (66,7 $\%)$.

Faktor usia juga sangat berpengaruh terhadap nyeri seseorang, usia merupakan variabel penting yang mempengaruhi nyeri, khususnya pada lanjut usia, individu lanjut usia memiliki risiko tinggi mengalami situasi - situasi yang membuat mereka merasakan nyei ( Potter \& Perry, 2005 )

Hasil penelitian menggambarkan bahwa sebagian besar responden adalah perempuan yaitu sebanyak 20 orang $(60,6 \%)$, hal ini dikarenakan responden perempuan lebih banyak dijumpai daripada responden laki-laki. Sehingga kesempatan responden perempuan untuk dilakukan penelitian lebih banyak dibandingkan laki- laki. dapat diketahui bahwa perbedaan antara sebelum melakukan kompres serei serei hangat adalah 5,47 dengan sesudah melakukan kompres serei hangat adalah 3,47. Hasil uji statistik didapatkan nilai $\mathrm{p}$ value $0,000(\leq 0,05)$ maka dapat disimpulkan ada perbedaan antara yang signifikan rata-rata antara skala nyeri sebelum dan sesudah melakukan kompres serei hangat.

Menurut asumsi peneliti, terdapat efektifitas kompres serei hangat terhadap penurunan skala nyeri arthritis rheumatoid pada lansia di Desa Naumbai wilayah kerja puskesmas Kampar 2019 karena kompres serei hangat bersifat vasodilatasi, meredakan nyeri dengan merelaksasi otot, menigkatkan aliran darah, dan meredakan nyeri dengan menghilangkan sumber peradangan yang menimbulkan nyeri. Dengan pemberian panas, pembuluh-pembuluh darah melebar sehingga akan memperlancar peredaran darah didalam jaringan. Dalam tanaman serai tekandung suatu enzim, yaitu enzim siklooksigenase yang dapat mengurangi peradangan 
yang diserap melalui kulit pada daerah yang meradang/bengkak pada penderita Arthritis Rheumtoid.

Hasil penelitian ini di dukung oleh penelitian yang dilakukan Ermala Sari pada tahun 2010, yang berjudul "Pengaruh penggunaan kompres hangat dalam pengurangan nyeri persalinan kala 1 fase aktif di Klinik $\mathrm{Hj}$. Hamidah Nasution Medan Tahun 2010" dimana penelitian ini mengatakan terdapat adanya pengaruh penggunaan kompres hangat terhadap penurunan nyeri persalinan kala 1 fase aktif.

Kompres serai hangat merupakan terapi alternatif yang dapat dilakukan secara mandiri untuk mengurangi rasa nyeri, karena serai mengandung senyawa aktif yang dapat menurunkan nyeri dan tanaman serai juga memeliki kandungan enzim siklo-oksigenase yang dapat mengurangi peradangan pada penderita arthritis rheumatoid, selain itu serai juga memiliki efek farmakologis yaitu rasa pedas yang bersifat hangat. Dimana efek panas ini dapat meredakan rasa nyeri, kaku dan spasme otot, karena terjadi vasodilatasi pembuluh darah (Smeltzer,2001).

Penelitian dari The Science and Tecnology menyebutkan serai memiliki manfaat antioksidan yang dapat membantu mencegah kanker, dalam serai terdapat

kandungan zat anti-mikroba dan anti bakteri yang berguna sebagai obat anti infeksi serta mengandung senyawa analgetik yang membantu menghilangkan rasa sakit atau nyeri seperti nyeri otot dan nyeri sendi akibat arthritis rheumatoid atau anti rematik.

Oleh karena perpaduan dari kompres serai dan hangatnya suhu air dan kandungan dari serai itu sendiri yang menjadikan nyeri artritis remathoid menurun secara kontinu. Banyak dari responden yang mengatakan ketika diberikan kompres serai nyerinya berkurang.

Penelitian ini juga di dukung oleh penelitian Ferawati tahun 2017, dimana hasil penelitian meyebutkan ada pengaruh kompres serai hangat terhadap penurunan intensitas nyeri arthritis rheumatoid pada lansia di Desa Mojoranu Kecamatan Dander Kabupaten Bojonegoro dikarenakan kompres serai hangat memiliki manfaat antioksidan yang dapat membantu mencegah kanker, dalam serai terdapat kandungan anti mikroba dan anti bakteri yang berguna sebagai obat infeksi serta mengandung senyawa analgetik yang membantu menghilangkan rasa sakit atau nyeri sendi akibat arthritis rheumatoid atau anti rematik.

Menurut asumsi peneliti, terjadinya penurunan skala nyeri arthritis rheumatoid dikarenakan tanaman serai mengandung minyak atsiri yang memiliki sifat kimiawi dan efek farmakologis yaitu rasa pedas dan bersifat hangat sebagai anti radang dan menghilangkan rasa sakit yang bersifat analgesik serta melancarkan sirkulasi darah yang diindikasikan untuk menghilangkan nyeri arthritis rheumatoid. Selain itu, menurut responden yang mendapatkan intervensi kompres serai hangat dapat meningkatkan rasa nyaman pada area yang di kompres sehingga nyeri berkurang

\section{KESIMPULAN}

Dari hasil penelitian yang dilakukan dengan judul “ efektifitas Kompres Serei Hangat Terhadap Penurunan Skala Nyeri Arthritis Rheumatoid pada Lansia di Desa Naumbai wilayah Kerja Puskesmas Kampar 2019 terdapat perbedaan skala nyeri responden sebelum dan sesudah kompres serai hangat pada lansia di desa Naumbai wilayah kerja puskesmas Kampar 2019 dengan nilai $p$-value $0,000 \leq 0,05$.

\section{DAFTAR PUSTAKA}

Baughman, D. C., Hackley, J. C., (2000), Keperawatan Medikal-Bedah Buku. Saku Dari Brunner \& Suddarth (Terjemahan), EGC, Jakarta.

Hidayat, A.A. (2009). Riset Keperawatan. Jakarta: Salemba Medika. Mansjoer Arif. (2001). Kapita Selekta Kedokteran. Jakarta : FKUI. Potter, P.A, Perry (2001) Buku Ajar Fundamental Keperawatan : Konsep, Proses, dan Praktik. Katalog Dalam Terbitan (KDT) 
Hidayat, A.A. (2012). Riset Keperawatan dan Teknik Penulisan Ilmiah. Jakarta : Salemba Medika

Hartatik, Indah Puji. 2014. Buku Praktis Mengembangkan SDM. Jogjakarta. Laksana.

Moekijat. 2008. Adminitrasi Perkantoran. Bandung: Mandar Maju.

Notoatmodjo. (2007). Metode Penelitian. Jakarta: Pustaka Belajar
Utami. (2005). Tanaman Obat Untuk Mengatasi Rematik dan Asam Urat. Agromedia Pustaka, Jakarta.

Potter, P.A., \& Perry. A.G. (2009). Fundamentals of Nursing : Fundamental Keperawatan (edisi 7). Jakarta: Salemba Medika (terjemahan).

Sudjana. (2005). Metode statistika. Bandung: Tarsito. 